\title{
Peranan Pompa Proton pada Pertumbuhan Escherichia coli di Lingkungan pH Alkali
}

\section{Roles of Proton Pumps in the Growth of Escherichia coli Under Alkaline pH Environment}

\author{
M. Yusuf ${ }^{1 *}$, H. Kurniawan ${ }^{1}$, A. B. R. Pahlevi ${ }^{1}$, Anton ${ }^{1}$, C. Budiman ${ }^{2}$, I. I. Arief ${ }^{2}$ \\ ${ }^{1}$ Program Studi Ilmu Produksi dan Teknologi Peternakan Fakultas Peternakan, \\ Sekolah Pascasarjana, Institut Pertanian Bogor, Bogor 16680 \\ ${ }^{2}$ Departemen Ilmu Produksi dan Teknologi Peternakan Fakultas Peternakan, \\ Institut Pertanian Bogor, Bogor 16680 \\ * Corresponding Author: m.yusuf08@yahoo.com
}

\begin{abstract}
Proton pump, which could be activated by sugar compound, is known to be involved in low pH adaptation in various bacteria. Indeed, we have previosuly confirmed that $E$. coli was also known to employ the pump for its adaptation at low $\mathrm{pH}$. Nevertheless, it remains to be confirmed if the growth of $E$. coli at alkaline $\mathrm{pH}$ also involves the similar mechanism, by which the pump is involved. This study aimed to analyze the growth of $E$. coli in broth media on alkaline $\mathrm{pH}$ and various concentration of glucose as an activator for the proton pump. The method used in this research was a completely randomized design factorial pattern, whereby the bacteria were grown in Luria-Bertani (LB) broth with different conditions. The growth curve was monitored using UV-vis absorbance at $600 \mathrm{~nm}$ and analyzed descriptively. The results showed that $\mathrm{pH}$ on the media greatly influenced the growth rate of $E$. coli bacteria. In general, E. coli grown in media with a $\mathrm{pH}$ of 12 requires a longer lag phase compared to $E$. coli grown on media with a $\mathrm{pH}$ of 7 . Addition of glucose at a concentration of $5 \%$ was able to improve the growth rate of E. coli in both media with $\mathrm{pH} 7$ and 12 . The conclusion of this study was environmental stress due to increased $\mathrm{pH}$ of the media can slow the growth rate of $E$. coli bacteria, where the addition of 5\% glucose can help improve E. coli growth rates. Altogether, glucose was found to have no serious effect on the growth of E. coli at alkaline $\mathrm{pH}$ which suggest that the involvment of proton pump for adaptation at the alkaline $\mathrm{pH}$ was minimum.
\end{abstract}

Key words: $E$. coli, growth chart, lag phase, $\mathrm{pH}$ alkaline

\begin{abstract}
ABSTRAK
Pompa proton, yang dapat diaktifkan oleh senyawa gula, diketahui terlibat dalam adaptasi $\mathrm{pH}$ rendah di berbagai bakteri. Kami telah mengkonfirmasi sebelumnya bahwa $E$. coli juga dikenal menggunakan pompa untuk adaptasinya pada $\mathrm{pH}$ rendah. Namun demikian, masih harus dikonfirmasi apakah pertumbuhan E. coli pada $\mathrm{pH}$ basa juga melibatkan mekanisme yang sama, dimana pompa terlibat. Penelitian ini bertujuan untuk menganalisis pertumbuhan E. coli dalam media Luria-Bertani (LB) pada $\mathrm{pH}$ basa dan berbagai konsentrasi glukosa sebagai aktivator untuk pompa proton. Metode yang digunakan dalam penelitian ini adalah rancangan acak lengkap pola faktorial, dimana bakteri ditanam dalam kaldu Luria-Bertani (LB) dengan kondisi yang berbeda. Kurva pertumbuhan diukur menggunakan absorbansi UV-vis pada $600 \mathrm{~nm}$ dan dianalisis secara deskriptif. Hasil penelitian menunjukkan bahwa $\mathrm{pH}$ pada media sangat mempengaruhi tingkat pertumbuhan bakteri $E$. coli. Secara umum, E. coli yang ditanam di media dengan $\mathrm{pH} 12$ membutuhkan fase lag yang lebih lama dibandingkan dengan E. coli yang ditanam di media dengan $\mathrm{pH}$ 7. Penambahan glukosa pada konsentrasi $5 \%$ mampu meningkatkan laju pertumbuhan $E$. coli di kedua media dengan $\mathrm{pH} 7$ dan 12. Kesimpulan dari penelitian ini adalah stres lingkungan karena peningkatan $\mathrm{pH}$ media dapat memperlambat laju pertumbuhan bakteri $E$. coli, dimana penambahan $5 \%$ glukosa dapat membantu meningkatkan tingkat pertumbuhan E. coli. Secara keseluruhan, glukosa ditemukan tidak memiliki efek serius pada pertumbuhan E. coli pada $\mathrm{pH}$ basa yang menunjukkan bahwa keterlibatan pompa proton untuk adaptasi pada $\mathrm{pH}$ basa adalah minimum.
\end{abstract}

Kata kunci: E. coli, fase adaptasi, grafik pertumbuhan, $\mathrm{pH}$ alkali

\section{PENDAHULUAN}

Salah satu bidang mikrobiologi modern yang menarik untuk dipelajari adalah mekanisme adaptasi suatu mikroorganisme terhadap stres lingkungan. Kemampuan mikroorganisme dalam merasakan dan merespon perubahan kondisi lingkungan disekitarnya menjadi sangat vital untuk keberlangsungan hidup mereka. Beberapa 
penelitian menunjukkan bahwa kemampuan berbagai jenis mikroorganisme dalam menghadapi cekaman stres lingkungan selalu ditandai dengan perubahan pada level genetik, biokimia dan struktur fisiknya. Masing-masing dari mikroorganisme tersebut memiliki suatu sistem strategi yang berbeda dalam merespon dan menghadapi single maupun multiple stress.

Kondisi stres lingkungan yang sering ditemukan di alam diantaranya adalah perubahan ketersediaan nutrisi (Bleotu et al., 2017; Costanzo dan Ades, 2006 ), cekaman panas (Noor et al., 2013), stres oksidatif (Desnues et al., 2003), dan juga perubahan $\mathrm{pH}$ pada media pertumbuhan (Wihansah et al., 2018). Beberapa jenis mikroorganisme termasuk di dalamnya bakteri Escherichia coli (Murata et al., 2012), Salmonella (Foster dan Spector, 1995), dan Pseudomonas (Givskov et al., 1994) terbukti mempunyai suatu mekanisme canggih pada intraselulernya dalam merespon perubahan yang terjadi pada lingkungan pertumbuhannya. Pada saat fase stasioner, dimana kondisi nutrisi di dalam media pertumbuhan sudah mulai habis, beberapa gen yang aktif terlibat dalam pertumbuhan $E$. coli akan berhenti ekspresi dan sebaliknya gen-gen yang tidak terlibat dalam pertumbuhan akan menjadi terekspresi (Ishihama, 1999).

Wihansah et al. (2018) melaporkan bahwa media Luria-Bertani (LB) broth yang telah diberi cekaman $\mathrm{pH}$ rendah $(\mathrm{pH}$ 4) terbukti mampu menghambat pertumbuhan bakteri $E$. coli. Lebih lanjut dijelaskan bahwa penambahan glukosa hingga 50\% mampu meningkatkan pertumbuhan bakteri E. coli hingga jam ke 29. Penambahan glukosa pada media pertumbuhan tersebut dimaksudkan untuk mendukung kinerja dari pompa proton. Pompa proton merupakan protein membran yang memiliki fungsi utama mengatur lalu lintas proton $(\mathrm{H}+)$ melalui membran sel atau organel sel. Fungsi transportasi proton oleh pompa ini terjadi melalui perubahan struktur/konformasi pompa yang diinduksi energi tertentu. Energi penginduksi tersebut bisa dari cahaya, transfer electron atau metabolit-metabolit yang kaya energi (Maurer et al., 2005). Lebih jauh dijelaskan bahwa pompa proton pada bakteri berfungsi untuk menjaga homeostasis $\mathrm{pH}$ internal tetap terjaga ketika $\mathrm{pH}$ eksternal bakteri menjadi asam.

Namun demikian, belum ada peneliti yang melaporkan apakah kemungkinan pompa proton tersebut juga bekerja pada saat $\mathrm{pH}$ eksternal bakteri menjadi sangat tinggi (pH basa). Berdasarkan uraian di atas, maka tujuan yang ingin dicapai dalam penelitian ini adalah untuk menganalisis pertumbuhan bakteri E. coli pada media LB broth yang diberi cekaman lingkungan basa dan penambahan konsentrasi glukosa yang berbeda sebagai bentuk respon toleransi basa. Pemilihan E. coli pada penelitian ini terutama karena pertumbuhan bakteri ini secara teknis mudah dan merupakan bakteri moderate yang memiliki $\mathrm{pH}$ optimum di rentang $\mathrm{pH}$ normal.

\section{MATERI DAN METODE}

Materi yang digunakan dalam penelitian ini adalah kultur bakteri E. coli yang diperoleh dari koleksi Laboratorium Terpadu, Departemen Ilmu Produksi dan Teknologi Peternakan, Fakultas Peternakan, Institut Pertanian Bogor. Bahan lain yang digunakan yaitu LB broth, miller (LuriaBertani, Difco, France), $\mathrm{NaOH}$ (Merck, Germany), dan glukosa (Merck, Germany). Peralatan yang digunakan dalam penelitian ini yaitu laminar air flow, timbangan analitik, pH meter elektronik (Schoot Instrument Lab 850, Jerman), tabung reaksi, autoclaf (TOMY, Japan), inkubator, mikropipet $(1000 \mu \mathrm{l}$ dan $100 \mu \mathrm{l})$, dan spektrofotometer (Agilent, UV-VIS 8453, China).

\section{Preparasi Media Kultur LB broth pH 7}

Preparasi media kultur LB broth $\mathrm{pH} 7$ dilakukan menurut metode yang dijelaskan oleh Wihansah et al. (2018) dengan sedikit modifikasi. Media LB broth sebanyak 2.5 gram ditambahkan dalam $100 \mathrm{ml}$ aquades dan dilarutkankan hingga homogen. Larutan selanjutnya diatur $\mathrm{pH}$-nya menggunakan $\mathrm{pH}$ 
meter elektronik dengan menambahkan $\mathrm{NaOH}$ hingga skala menunjukkan $\mathrm{pH} 7$.

Sebelum digunakan, alat $\mathrm{pH}$ meter dibersihkan terlebih dahulu pada bagian katoda indikatornya, dengan dicuci menggunakan aquades kemudian dikeringkan dengan tissue. Alat $\mathrm{pH}$ meter selanjutnya dikalibrasi dengan larutan buffer $\mathrm{pH} 4$ dan 7 dengan mencelupkan bagian ujung katodanya, selanjutnya ujung katoda dicelupkan dalam larutan media, setelah muncul kata "ready" angka yang muncul dicatat dan dibaca sebagai skala nilai $\mathrm{pH}$ larutan media. Larutan yang sudah diatur $\mathrm{pH}-$ nya selanjutnya didistribusikan ke dalam 8 tabung reaksi masing-masing sebanyak $10 \mathrm{ml}$ menggunakan gelas ukur. Larutan selanjutnya ditambahkan glukosa dengan konsentrasi yang berbeda yaitu $0,5,10$, dan $20 \%$, masing masing perlakuan terdiri dari dua tabung reaksi. Larutan yang sudah siap kemudian diberi label dan disterilisasi menggunakan autoclave pada suhu $121{ }^{\circ} \mathrm{C}$ selama 15 menit.

\section{Preparasi Media Kultur LB broth pH 12}

Preparasi media kultur LB broth $\mathrm{pH}$ 12 dilakukan menurut metode yang dijelaskan oleh Wihansah et al. (2018) dengan sedikit modifikasi. Media LB broth sebanyak 2.5 gram ditambahkan dalam 100 $\mathrm{ml}$ aquades dan dilarutkan hingga homogen. Larutan selanjutnya diatur pH-nya menggunakan $\mathrm{pH}$ meter elektronik dengan menambahkan $\mathrm{NaOH}$ hingga skala menunjukkan $\mathrm{pH}$ 12. Sebelum digunakan, alat $\mathrm{pH}$ meter dibersihkan terlebih dahulu pada bagian katoda indikatornya, dengan dicuci menggunakan aquades kemudian dikeringkan dengan tissue. Alat $\mathrm{pH}$ meter selanjutnya dikalibrasi dengan larutan buffer $\mathrm{pH} 4$ dan 7 dengan mencelupkan bagian ujung katodanya, selanjutnya ujung katoda dicelupkan dalam larutan media, setelah muncul kata "ready" angka yang muncul dicatat dan dibaca sebagai skala nilai $\mathrm{pH}$ larutan media. Larutan yang sudah diatur $\mathrm{pH}-$ nya selanjutnya didistribusikan ke dalam 8 tabung reaksi masing-masing sebanyak $10 \mathrm{ml}$ menggunakan gelas ukur. Larutan selanjutnya ditambahkan glukosa dengan konsentrasi yang berbeda yaitu $0,5,10$, dan $20 \%$, masing masing perlakuan terdiri dari dua tabung reaksi. Larutan yang sudah siap kemudian diberi label dan disterilisasi menggunakan autoclave pada suhu $121{ }^{\circ} \mathrm{C}$ selama 15 menit.

\section{Preparasi Pre-kultur Bakteri E. coli}

Persiapan pre-kultur dilakukan berdasarkan metode yang dijelaskan oleh Sekse et al. (2012) dengan menumbuhkan isolat bakteri E. coli pada $10 \mathrm{ml}$ media LB broth yang sudah disterilkan, kemudian diinkubasi pada suhu $37{ }^{\circ} \mathrm{C}$ selama 24 jam. Kultur yang telah disegarkan kemudian diinokulasi sebanyak $2 \%$ ke dalam $10 \mathrm{ml}$ media LB broth yang baru, selanjutnya diinkubasi kembali pada suhu $37{ }^{\circ} \mathrm{C}$ overnigh (12-16 jam). Kultur E. coli siap digunakan untuk analisis lebih lanjut.

\section{Inokulasi Bakteri $E$. coli dan Pengamatan Optical Density (Metode Turbidimetri)}

Proses inokulasi bakteri E. coli dilakukan secara aseptik dalam ruang laminar mengikuti prosedur yang telah dijelaskan oleh Sekse et al. (2012). Sebanyak $100 \mu 1$ prekultur ditambahkan ke dalam tabung reaksi pada masing-masing perlakuan menggunakan mikropipet. Pencegahan kontaminasi dilakukan dengan melapisi bagian penutup tabung reaksi menggunakan plastik wrap. Kultur E. coli selanjutnya diinkubasi dalam inkubator pada suhu $37{ }^{\circ} \mathrm{C}$ selama 30 jam.

Pengamatan jumlah bakteri dilakukan berdasarkan tingkat kekeruhan kultur yang diamati secara spectrofotometris. Pengamatan ini dimulai pada jam ke-0 dan dilanjutkan setiap 3 jam berikutnya hingga jam ke-30. Masing-masing perlakuan diamati pertumbuhan jumlah bakterinya dengan memipet sebanyak $100 \quad \mu l$ sampel dan dimasukkan ke dalam cuvet yang sebelumnya sudah disterilkan menggunakan etanol. Pengukuran optical density dilakukan pada panjang gelombang $600 \mathrm{~nm}$. Data yang sudah diperoleh selanjutnya direkap ke dalam Ms. Excel untuk dianalisis. 


\section{Analisis Data}

Penelitian ini menggunakan rancangan acak lengkap (RAL) pola faktorial. Faktor pertama adalah cekaman $\mathrm{pH}$ basa yaitu $\mathrm{pH} 7$ dan $\mathrm{pH}$ 12, sedangkan faktor kedua adalah konsentrasi glukosa yaitu $0,5,10$, dan 20\%. Variabel yang diamati adalah jumlah bakteri. Data yang diperoleh dianalisis menggunakan Microsoft Excel, dan ditampilkan dalam bentuk tabel dan grafik serta dianalisis secara deskriptif.

\section{HASIL DAN PEMBAHASAN}

Hasil analisis optical density (OD) bakteri E. coli dengan UV-vis spektrofotometer pada panjang gelombang 600 nm disajikan pada Tabel 1. Pada penelitian ini, E. coli ditumbuhkan pada media LB broth dengan $\mathrm{pH} 7$ dan 12 dengan penambahan $\mathrm{NaOH}$. Berdasarkan data tersebut, terlihat bahwa setiap perlakuan memiliki nilai absorbansi yang berbeda, perbedaan nilai absorbansi tersebut mengindikasikan perbedaan jumlah bakteri yang tumbuh.

Nilai absorbansi E. coli pada seluruh perlakuan (P0- P7) mengalami penurunan nilai absorbansi hingga jam ke-3 untuk media dengan $\mathrm{pH} 7$ dan hingga jam ke-6 untuk media dengan $\mathrm{pH} 12$ (Tabel 1). Hal ini berarti bahwa terjadi penurunan jumlah bakteri pada tiga hingga enam jam awal pertumbuhan. Penurunan jumlah bakteri ini mungkin disebabkan karena $E$. coli sedang berada pada fase adaptasi. Fase adaptasi atau yang sering disebut lag phase merupakan fase ketika bakteri tidak aktif membelah namun sedang menyesuaikan diri dengan lingkungan barunya dalam upaya untuk bertahan hidup (Rolfe et al., 2012).

Tabel 1. menunjukkan adanya peningkatan nilai absorbansi yang lebih tinggi pada media dengan $\mathrm{pH} 7$ dibandingkan dengan media pada $\mathrm{pH} 12$, kemungkinan hal tersebut terjadi akibat stres lingkungan pada $\mathrm{pH}$ basa. Jika dibandingkan dengan penelitian yang dilakukan oleh Wihansah et al. (2018), pertumbuhan E. coli pada penelitian ini terlihat lebih baik, khususnya pada media dengan $\mathrm{pH}$ 7. Kondisi ini sesuai dengan hasil penelitian yang dilakukan oleh Kim et al. (2018), dimana beberapa jenis bakteri patogen seperti $B$. cereus, E. coli, $L$. monocytogenes, $S$. aureus dan Salmonella spp yang ditumbuhkan pada media dengan $\mathrm{pH}$ yang berbeda ( $\mathrm{pH}$ 5-10) menunjukkan tingkat pertumbuhan yang lebih rendah pada $\mathrm{pH}$ asam dari pada $\mathrm{pH}$ basa.

Tabel 1. Hasil pengamatan optical density bakteri E. coli

\begin{tabular}{ccccccccc}
\hline $\begin{array}{c}\text { Waktu } \\
\text { (jam) }\end{array}$ & P0 & P1 & P2 & P3 & P4 & P5 & P6 & P7 \\
\hline 0 & 0,23 & 0,25 & 0,23 & 0,25 & 0,19 & 0,68 & 0,51 & 0,28 \\
3 & 0,18 & 0,16 & 0,10 & 0,12 & 0,08 & 0,50 & 0,51 & 0,24 \\
6 & 0,52 & 0,79 & 0,41 & 0,16 & 0,01 & 0,53 & 0,45 & 0,24 \\
9 & 0,66 & 1,84 & 1,19 & 0,10 & 0,12 & 0,77 & 0,52 & 0,29 \\
12 & 2,18 & 1,96 & 0,90 & 0,86 & 0,13 & 0,91 & 0,47 & 0,00 \\
15 & 1,98 & 1,49 & 0,88 & 0,95 & 0,07 & 1,16 & 0,62 & 0,00 \\
18 & 1,88 & 1,53 & 0,95 & 0,98 & 0,08 & 1,30 & 0,79 & 0,00 \\
21 & 1,84 & 1,47 & 1,14 & 0,98 & 0,07 & 1,21 & 0,91 & 0,00 \\
24 & 0,85 & 2,34 & 1,69 & 0,94 & 0,19 & 1,68 & 0,85 & 0,42 \\
27 & 0,81 & 2,50 & 2,02 & 0,99 & 0,08 & 1,62 & 0,67 & 0,35 \\
30 & 0,78 & 2,49 & 1,63 & 0,92 & 0,17 & 1,99 & 1,02 & 0,37 \\
\hline
\end{tabular}

Keterangan: $\mathrm{P} 0=\mathrm{LB}$ Broth $\mathrm{pH} 7+0 \%$ glukosa, $\mathrm{P} 1=\mathrm{LB}$ Broth $\mathrm{pH} 7+5 \%$ glukosa, $\mathrm{P} 2=\mathrm{LB}$ Broth $\mathrm{pH} 7+10 \%$ glukosa, P3 = LB Broth pH $7+20 \%$ glukosa, $\mathrm{P} 4=\mathrm{LB}$ Broth $\mathrm{pH} 12+0 \%$ glukosa, $\mathrm{P} 5=\mathrm{LB}$ Broth $\mathrm{pH} 12+5 \%$ glukosa, P6 = LB Broth $\mathrm{pH} 12+10 \%$ glukosa, P12 = LB Broth $\mathrm{pH} 12+20 \%$ glukosa. 
Pemberian glukosa dengan beberapa level yang berbeda $(0,5,10$, dan $20 \%)$ pada media dengan $\mathrm{pH} 7$ dan 12, menunjukkan hubungan yang tidak linier. Pada penelitian ini, penambahan persentase glukosa yang semakin tinggi tidak diikuti oleh tingkat pertumbuhan E. coli yang baik. Hal tersebut berbeda dengan hasil penelitian yang dilakukan oleh Wihansah et al. (2018), dimana semakin tinggi persentase glukosa yang diberikan, maka tingkat pertumbuhana E. coli nya semakin baik. Secara umum, terlihat bahwa pada penambahan glukosa $5 \%$ baik pada pH 7 maupun pH 12 menunjukkan tingkat pertumbuhan $E$. coli yang lebih baik.

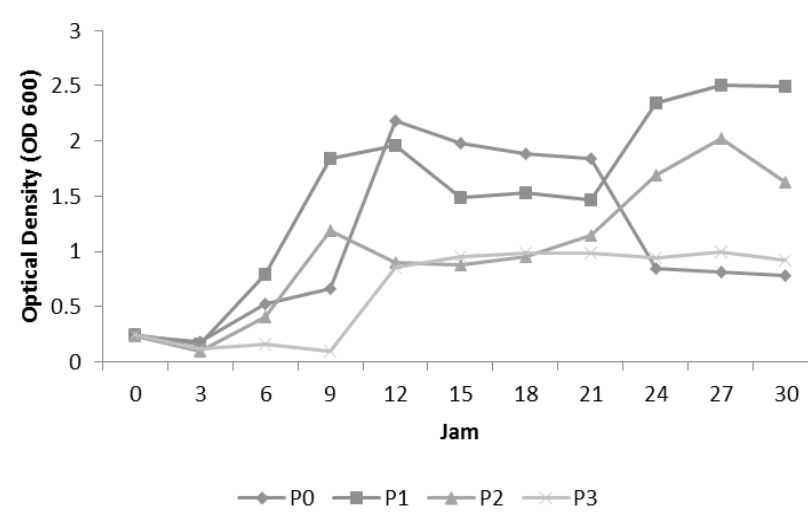

Keterangan: $\mathrm{P} 0=\mathrm{LB}$ Broth $\mathrm{pH} 7+0 \%$ glukosa, $\mathrm{P} 1=$ LB Broth $\mathrm{pH} 7+5 \%$ glukosa, $\mathrm{P} 2=\mathrm{LB}$ Broth $\mathrm{pH} 7+$ $10 \%$ glukosa, $\mathrm{P} 3=\mathrm{LB}$ Broth $\mathrm{pH} 7+20 \%$ glukosa.

Gambar 1. Grafik pertumbuhan bakteri E. coli pada $\mathrm{pH} 7$

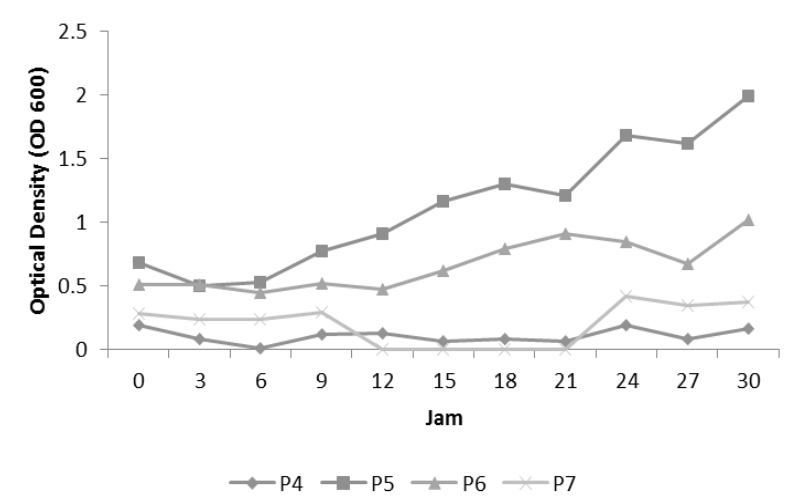

Keterangan: $\mathrm{P} 4=\mathrm{LB}$ Broth $\mathrm{pH} 12+0 \%$ glukosa, $\mathrm{P} 5=$ LB Broth $\mathrm{pH} 12+5 \%$ glukosa, P6 = LB Broth $\mathrm{pH} 12$ $+10 \%$ glukosa, $\mathrm{P} 12=\mathrm{LB}$ Broth $\mathrm{pH} 12+20 \%$ glukosa.

Gambar 2. Grafik pertumbuhan bakteri E. coli pada $\mathrm{pH} 12$
Grafik pertumbuhan bakteri E. coli yang ditumbuhkan pada media dengan $\mathrm{pH} 7$ dan pH 12 disajikan pada Gambar 1 dan 2. Pada 3 jam awal inkubasi, E. coli yang ditumbuhkan pada media LB broth dengan pH 7 mengalami sedikit penurunan tingkat pertumbuhannya. Hal ini mengindikasikan 3 jam tersebut merupakan fase adaptasi (lag phase), kecuali pada perlakuan P3 yang memiliki fase adaptasi lebih lama hingga 9 jam. Pertumbuhan E. coli mengalami peningkatan yang tajam dimulai pada jam ke3 hingga jam ke-12. Hal tersebut mengindikasikan E. coli sedang memasuki fase eksponensial (log phase). Pertumbuhan E. coli selama fase eksponensial pada $\mathrm{P} 1$ terlihat lebih tinggi dibandingkan dengan $\mathrm{P} 0$, hal tersebut disebabkan karena adanya penambahan glukosa sebanyak 5\% sebagai sumber energi.

Bakteri E. coli yang ditumbuhkan pada media dengan $\mathrm{pH} 12$, menunjukkan fase adaptasi yang lebih lama (Gambar 2) dibandingkan pada media dengan $\mathrm{pH}$ 7. Hal tersebut mengindikasikan bahwa penghambatan pertumbuhan $E$. coli dengan pengaturan $\mathrm{pH}$ media menjadi sangat basa (pH 12) memungkinkan E. coli untuk lebih lama dalam menghadapi agen stres. Beberapa penelitian telah melaporkan tentang bagaimana cara suatu mikroorganisme dapat beradaptasi dan bertahan hidup pada lingkungan dengan berbagai cekaman. Salah satu cara yang dapat dilakukan adalah dengan mensintesis protein yang disebut sebagai shock protein (Ohtsuka et al., 2007). Selain mensintesis protein, bakteri akan mengaktifkan pompa proton dalam mengatur homeostasis $\mathrm{pH}$ internal, ketika lingkungan eksternal bakteri tersebut menjadi asam (Maurer et al., 2005).

Mekanisme adaptasi E. coli pada cekaman $\mathrm{pH}$ rendah dilakukan dengan cara mensintesis protein yang dikenal sebagai acid shock proteins (ASPs) dan aktivasi pompa proton dengan cara memompa proton keluar sel (Booth et al., 2002; Maurer et al., 2005). Pada penelitian yang dilakukan oleh Wihansah et al. (2018), peningkatan persentase glukosa yang diberikan akan 
mengakibatkan tingkat pertumbuhan E. coli semakin baik. Hal tersebut dikarenakan glukosa berperan sebagai sumber energi untuk kinerja pompa proton. Pada penelitian ini, pemberian glukosa yang semakin tinggi, tidak mengakibatkan tingkat pertumbuhan $E$. coli yang semakin baik. Hal tersebut mengindikasikan mekanisme adaptasi E. coli pada $\mathrm{pH}$ basa tidak melibatkan pompa proton melainkan dengan sintesis protein. Meskipun demikian, ketidak terlibatan pompa proton dalam adaptasi $\mathrm{pH}$ basa masih harus diteliti lebih lanjut dari sisi molekuler.

Secara teori pompa proton secara spesifik mengatur lalu lintas ion $\mathrm{H}+$ (asam) untuk menjaga $\mathrm{pH}$ internal sel. Sementara itu, lingkungan yang basa ditandai dengan tingginya ion hidroksil $(\mathrm{OH}-)$, bukan $\mathrm{H}+$. Peranan pompa proton dalam menetralisir $\mathrm{pH}$ basa bisa dilakukan dengan mentransportasi ion $\mathrm{H}+\mathrm{ke}$ dalam sel dengan jumlah lebih banyak. Akan tetapi hal ini rupanya tidak terjadi pada E. coli dalam penelitian ini. Salah satu sebabnya mungkin adalah upaya sel mencegah terjadinya sel disrupsi akibat molekul air yang terlalu banyak di dalam strukturnya. Ketika pompa proton mengambil ion $\mathrm{H}+$ yang terlalu banyak, ion ini akan bereaksi dengan ion hidroksil dan menghasilkan molekul air. Semakin banyak ion $\mathrm{H}+$, semakin banyak pula molekul air yang terbentuk sehingga menimbulkan tekanan dalam sel yang jauh lebih tinggi (akibat konsentrasi air naik) dan bisa merusak dinding sel.

Atas dasar tersebut, mekanisme adaptasi $\mathrm{pH}$ basa oleh $E$. coli diduga bukan melibatkan (atau minimal) pompa proton, tetapi lebih ke arah sintesis protein-protein spesifik yang terlibat dalam cekaman $\mathrm{pH}$ basa. Yohannes et al. (2004) melaporkan bahwa setidaknya ada 19 jenis protein yang kadarnya meningkat saat cekaman $\mathrm{pH}$ tinggi, protein tersebut adalah jenis protein periplasmik, protein stres, dan enzim metabolisme. Lebih jauh dijelaskan bahwa enzim metabolisme ini akan merangsang peningkatan fermentasi menjadi asam, sehingga akan menetralkan alkali.

\section{KESIMPULAN}

Berdasarkan hasil penelitian dapat disimpulkan bahwa media LB broth dengan $\mathrm{pH}$ yang tinggi $(\mathrm{pH} 12)$ dapat menyebabkan fase adaptasi (lag phase) E. coli yang lebih lama dari pada $\mathrm{pH}$ netral ( $\mathrm{pH} 7)$. Selain itu, penambahan glukosa sebanyak 5\% dapat memberikan performa terbaik untuk membantu pertumbuhan E. coli.

\section{DAFTAR PUSTAKA}

Bleotu, C., M. C. Chifiriuc, D. Mircioagă, O. Săndulescu, I. M. Aldea, O. Banu, D. Ion, C. C. Diaconu, F. Marinescu, and V. Lazăr. 2017. The influence of nutrient culture media on Escherichia coli adhesion and biofilm formation ability. Romanian Biotechnological Letters. 22 (2): 1248312491.

Booth, I. R., P. Cash, and C. O. Byrne. 2002. Sensing and adapting to acid stress. Anton von Leeuwenhoek. 81: 33- 42.

Costanzo, A. and S. E. Ades. 2006. Growth phase-dependent regulationof the extracytoplasmic stress factor, $\sigma^{\mathrm{E}}$, guanosine 3', 5'-bispyrophosphate (ppGpp). J. Bacteriol. 188: 4627-4634.

Desnues, B., C. Cuny, G. Gre'gori, S. Dukan, H. Aguilaniu, and T. Nystro"m. 2003. Differential oxidative damage and expression of stress defense regulons in culturable and nonculturable Escherichia coli cells. EMBO Rep. 4: 400-404.

Foster, J.W. and M. P. Spector. 1995. How Salmonella survives against the odds. Annu Rev Microbiol. 49: 145-174.

Givskov, M., L. Eberl, S. Moller, L. K. Poulsen, and S. Molin. 1994. Responses to nutrient starvation in Pseudomonas putida KT2442: analysis of general cross-protection, cell shape, and macromolecular content. J. Bacteriol. 176: 7-14.

Ishihama, A. 1999. Modulation of the nucleoid, the transcription apparatus, and the translation machinery in bacteria for 
stationary phase survival. Genes Cells. 4: 135-143.

Kim, C., K. Wilkins, M. Bowers, C. Wynn, and E. Ndegwa. 2018. Influence of $\mathrm{pH}$ and temperature on growth characteristics of leading foodborne pathogens in a laboratory medium and select food beverages. Austin Food Sci. 3(1): 1031.

Maurer, L. M., E. Yohannes, S. S. Bondurant, M. Radmacher, and J. L. Slonczewski. 2005. $\mathrm{pH}$ regulates genes for flagellar motility, catabolism, and oxidative stress in Escherichia coli K-12. J. Bacteriol. 187(1): 304-319.

Murata, M., R. R. Noor, H. Nagamitsu, S. Tanaka, and M. Yamada. 2012. Novel pathway directed by $\mathrm{r}^{\mathrm{E}}$ to cause cell lysis in Escherichia coli. Genes to Cells. 17: 234-247.

Noor, R. R., Z. Islam, S. K. Munshi, and F. Rahman. 2013. Influence of temperature on Escherichia coli growth in different culture media. J Pure Appl Microbio. 7(2): 899-904.

Ohtsuka, K., D. Kawashima, and M. Asai. 2007. Dual functions of heat shock proteins: molecular chaperones inside the cell and danger signals outside of cells. Thermal Med. 23:11-22.
Rolfe, M. D., C. J. Rice, S. Lucchini, C. Pin, A. Thompson, A. D. S. Cameron, M. Alston, M. F. Stringer, R. P. Betts, J. Baranyi, M. W. Peck, and C. J. D. Hintona. 2012. Lag phase is a distinct growth phase that prepares bacteria for exponential growth and involves transient metal accumulation. Journal of Bacteriology. 194(3): 686-701.

Sekse, C., J. Bohlin, E. Skjerve, and G. E. Vegarud. 2012. Growth comparison of several Escherichia coli strains exposed to various concentrations of lactoferrin using linear spline regression. Microb. Inform. Exp. 2 (5): 1-12.

Wihansah, R. R. S., M. Yusuf, M. Arifin, A. Y. Oktaviana, Rifkhan, J. K. Negara, and A. K. Sio. 2018. Pengaruh pemberian glukosa yang berbeda terhadap adaptasi Escherichia coli pada cekaman lingkungan asam. JSPI. 13 (1): 29-35.

Yohannes, E., D. M. Barnhart, and J. L. Slonczewski. 2004. pH-dependent catabolic protein expression during anaerobic growth of Escherichia coli $\mathrm{K}$ 12. Journal of Bacteriology. 186(1): 192199. 